PRINT ISSN 1119-8362

Electronic ISSN 1119-8362
Full-text Available Online at https://www.ajol.info/index.php/jasem

http://ww.bioline.org.br/ja
J. Appl. Sci. Environ. Manage.

Vol. 23 (8) 1437-1444 August 2019

\title{
Potential of Snail Shell and Palm Kernel Shell Powders in Improving Engineering Properties of Clay
}

\author{
*AYODELE, FO; POPOOLA, OO
}

\author{
Department of Civil Engineering, The Federal Polytechnic, Ado-Ekiti, Ekiti State, Nigeria \\ *Corresponding Author Email: ayodele_fo@fedpolyado.edu.ng; other Email: popoolaoluniyi@gmail.com
}

\begin{abstract}
This research is aimed at using Snail Shell Powder (SSP) and Palm Kernel Shell Powder (PKSP) in stabilizing clay. Elemental and oxide compositions of the powders were determined and they revealed SSP is richer in $\mathrm{CaO}$ than PKSP. Sieve Analysis, Compaction, California Bearing Ratio (CBR) and Atterberg Limit were conducted on natural and stabilized soil mixture. The natural soil (A-7-6) was blended with SSP and PKSP at varying proportion of $2 \%$, $4 \%, 6 \%, 8 \%$, and $10 \%$ by dry weight of soil respectively and also combined at ratios not more than $10 \%$ total . Inclusion of additives increase the Maximum Dry Density (MDD) while it predominantly decrease the Optimum Moisture Content $(\mathrm{OMC})$ values of the stabilized soil mixture. Plasticity Index (PI) decrease with the addition of the powders with the best performance observed mostly with SSP blended soil. It was also found that the CBR values of soil increase with corresponding increase in dosage of the powders. Soil blended with $8 \%$ SSP offered the best result with increase in MDD from 1198 to $1300 \mathrm{~kg} / \mathrm{m}^{3}$ while the combined additives gave the best result at $2 \% \mathrm{SSP}+8 \% \mathrm{PKSP}$ addition with MDD increasing to $1266 \mathrm{~kg} / \mathrm{m}^{3}$ and further reduction of OMC to $21 \%$. The best results in PI were from Soil blended with $2 \%$ SSP and also $2 \% \mathrm{SSP}+8 \mathrm{PKSP}$ with $6.25 \%$ and $9.2 \%$ respectively. For CBR, soil blended with $8 \% \mathrm{SSP}$ and $2 \% \mathrm{SSP}+8 \mathrm{PKSP}$ of combined ratio gave peak performances. The potential of these additives in improving soil properties and reducing construction cost of road are presented.
\end{abstract}

\section{DOI: https://dx.doi.org/10.4314/jasem.v23i8.5}

Copyright: Copyright (C) 2019 Ayodele and Popoola. This is an open access article distributed under the Creative Commons Attribution License (CCL), which permits unrestricted use, distribution, and reproduction in any medium, provided the original work is properly cited.

Dates: Received: 06 June 2019; Revised: 22 July 2019; Accepted 02 August 2019

Keywords: Palm kernel shell Powder, Snail shell powder, Clay stabilization, Geotechnical properties.

Clay soil is available almost everywhere in the world and depending on its intended use; its geotechnical properties may need to be improved. The need for soil stabilization arises whenever the engineering properties of natural soil is poor or when a section of the land is found not suitable to support the foundation in its natural state as well as when there is need to reduce the cost of construction especially in road pavement (Ogundipe,2013).

There are various methods of soil improvement but chief among them often used for highways is stabilization using admixtures. Stabilization which is basically the optimization of constituent materials properties. It can be achieved either by mechanical means, physical means or addition of chemical. Chemically stabilized soils are composite materials containing natural soil and at least one or more materials (Basha et al., 2005). The material (natural or synthetic material) is purposely added to improve the engineering properties of the natural soil. Although, Portland cement, lime and sometimes bitumen are the most commonly used stabilizers of soils (Basha et al., 2005; Hossain et al., 2007; Vilane 2010). Their production releases harmful gases to the environment which in turn contributes to global warming. It has been indisputably established that the cement industry is a major source of $\mathrm{CO}_{2}$ emissions contributing about $5 \%$ to global anthropogenic $\mathrm{CO}_{2}$ emissions with an average intensity of carbon dioxide emissions from total global cement production of $222 \mathrm{~kg}$ of $\mathrm{C} / \mathrm{t}$ of cement. This is due to its dominant use of carbonintensive fuels, such as coal in clinker making (Worrell et al., 2001). On the other hand, lime which is a term often used to mean quick lime $(\mathrm{CaO})$ and hydrated lime $\left(\mathrm{Ca}(\mathrm{OH})_{2}\right)$, is also one of the basic materials used in the construction industry. Although, there use in construction industry in Nigeria is low compared to cement as most of the products used for its production is sourced from abroad. Just like in the production of cement, its production releases harmful gases (pollutants) which include dust, $\mathrm{SO}_{2}, \mathrm{NO}_{\mathrm{x}}$ and HCL.

Consequent upon the increasingly environmental impacts such as carbon emission associated with the production of cement and lime, there is a serious global focus on the utilization of locally available materials, agricultural waste and by-products in the construction industry. In most developing countries and Nigeria in particular where there are no sanitary landfills; household wastes, agricultural by-products 
and waste litters the streets. Generally, large quantities of wastes generated in Nigeria are from agriculture (Edewor and Jemni 1990); while materials including palm kernel shell specifically are largely available in the southern zone of the country (Olanipekun et al., 2006). Although, information on the quantities of agro-waste or agricultural product generated in Nigeria man not be available and estimates of agricultural waste are rare. These agro waste generally contributes significantly to the total waste matter in the Nigeria (Obi et al., 2016).

However, the generation of wastes and its disposal are ever more becoming a major concern globally (Gardner 2011; Gomes et al., 2011; Hossain et al., 2011; Osinubi and Edeh 2011; Wen and Wu 2011). Reports and investigations has shown that these waste products can be adapted for use as soil stabilizer or other construction materials if suitably applied. Although, it may be practically impossible to do without the conventional stabilizers; a reasonable fraction can be substituted or partially replaced. Therefore, in a bid to provide sustainable (economically, socially and environmentally) materials for construction purposes, preserve natural resources, reduce heaps of voluminous wastes and ultimately reduce construction cost; the applicability of several agro waste materials have been investigated. Several scholars have reported the suitability of some agro wastes and industrial by-products as alternative construction materials. The applicability of these waste by-products has been in various forms. They are used in fiber, calcinated ash, shell forms These materials include among others Rice Husk (Oluwatuyi and Ojuri 2017; Phanikumar and Nagaraju 2018), Coconut Shell and Coir (Oyedepo et al., 2015; Sanjay and Rajeev 2015; Ashish Johnson and Krishnankutty 2017), Sugarcane Baggase (Alavez-Ramirez et al., 2012; Abdulkadir et al., 2014; Salim et al., 2014; Danso et al., 2015), Egg Shell (Amu and Salami 2010; Jiksymol et al., 2014; Johns et al., 2017; Karthika et al., 2016; Kavyashree et al., 2016; Okonkwo et al., 2012), Cassava peel (Salau et al., 2012; Bello et al., 2015; Olutaiwo and Adanikin 2016), Groundnut Shell (Nnochiri and Ogundipe 2016; Sujatha et al., 2016), Saw dust (Ogunribido 2012; Ayeni and Ayodele 2015; Butt et al., 2016), Palm Kernel Shell (Edeh et al., 2012; Adetoro and Faluyi 2015; Nnochiri et al., 2017), Fly Ash (Phanikumar and Sharma 2007; Okunade 2010; Phanikumar and Nagaraju 2018), dusts (Sunil et al., 2016; Igwe and Adepehin 2017; Duc and Onyelowe 2018), Bamboo (Amu and Adetuberu 2010; Olofintuyi et al., 2015; Brahmachary and Rokonuzzaman 2018).etc. Few researches have been carried out on using the powder form of the waste except sea shell powder (Mounika, et al., 2014) and eggshell powder. Therefore, putting in context the availability of palm kernel shell and snail shell in Nigeria owing to her been an agrarian country and the present economy: there is a persuasive need to look towards its use, being a cheap and readily available alternative materials. In this research, clay soil is modified with snail shell and palm kernel shell powders and subjected to some geotechnical investigation with the aim of providing the applicability of Snail Shell Powder and Palm Kernel Shell Powder in stabilizing clay soil.

\section{MATERIALS AND METHOD}

Materials: Natural clay soil, eggshell powder, palm kernel shell powder and water were used.The clay soil sample was collected at a clay deposit along Ise - Ikere Road, Ikere-Ekiti, Ekiti State, Nigeria at $7^{\circ} 49^{\prime} 18^{\prime \prime} N$ latitude and $5^{\circ} 24^{\prime} 19^{\prime \prime} E$ Longitude. Ikere clay are predominantly kaolinite and has a clayeyness of 0.7 (Akinyemi et al., 2014). Snail shell and palm kernel shell were sourced from local farms in Ado-Ekiti, Nigeria. Potable water was used in mixing the powders with the soil.

Sampling and preparation: Clay sample was collected at $500 \mathrm{~mm}$ depth below the ground level. The sample was taken to the laboratory in a watertight and airtight polythene bag for further treatment and use. Palm kernel shell was sun-dried and milled while Snail shell was sun-dried and grinded. The powders (PKSP and SSP) were sieved through $75 \mu \mathrm{m}$ sieve size. Powders of $0,2,4,6,8$ and $10 \%$ by weight of the dry clay sample was mixed with the samples.

Physical properties of soil: Tests including soil index properties, classification tests as well as strength properties test were performed on the natural and modified clay sample. These tests are natural moisture content, specific gravity, particle size distribution, consistency (Atterberg) limits while compaction tests, Triaxial test and California Bearing Ratio were performed on the soil to determine strength properties. These laboratory tests were conducted at the Soil Mechanics laboratory of The Federal Polytechnic Ado-Ekiti in conformity with. BS 1377-2. (1990).

Chemical properties of additives: The elemental and oxide composition of the powders were determined using Atomic Absorption Spectrometry (AAS) and XRay Fluorescence (XRF). They were carried out at the Chemical Laboratory of Afe Babalola University, Ado-Ekiti, Ekiti State and National Agency for Science and Engineering Infrastructure (NASENI) CoEx Laboratory, Akure, Ondo State respectively. The mineral content of the digested sample was analyzed using Atomic Absorption Spectrophotometer 
(Buck Scientific 210 VGP) and UV Visible Spectrophotometer (PG T60U) and their oxides were calculated using a conversion table.

Skyray EDX3600B X-ray fluorescence spectrometer was used to determine elemental composition of the powders. The system detects elements between Sodium (Na, Z=11) and Uranium (U, Z =92) with high resolution and fast analysis. After each powder sample was pulverized to fine homogeneous size and then pelletized. The following steps were adopted: Initialization (calibration) using pure silver sample. The working curve according to the sample was selected Sample was tested and the output was processed to an excel sheet.

\section{RESULTS AND DISCUSSION}

Properties of the soil and the additives: The tests conducted on the natural clay soil including sieve analysis, Specific gravity, consistency limit test, compaction, California Bearing ratio (CBR) are shown in Table 1. The particle size distribution shows the soil contains $94.48 \%$ fines with silt being the predominant material of $78.88 \%$. The clay fraction is observed to be $15.6 \%$.The plasticity which is the behaviour of soil when there is changes in moisture was also observed. Plasticity Index of 21.8 indicates that the soil is of medium plasticity. Owing to the results obtained from some preliminary tests, the soil is classified as CL and A-7-6 being classification for USCS and AASHTO system respectively. The soil Group Index (GI) of 23.2 infers that the soil is very poor. The chemical composition of the soil shown in Table 2 revealed that the soil has $40.58 \%$ composition of $\mathrm{SiO}_{2}$ being the highest and $0 \%$ of $\mathrm{CaO}$, the lowest. Tables 3 and 4 describes the oxide and elemental composition of the additives. It is observed that the main oxide contained in both SSP and PKSP is $\mathrm{CaO}$, with a value of $25.7 \%$ for the former while the latter contains $7.5 \%$.

Table 1.Summary of physical properties of the soil

\begin{tabular}{|c|c|c|c|}
\hline \multicolumn{4}{|c|}{ Particle Size Distribution } \\
\hline \multirow{8}{*}{ 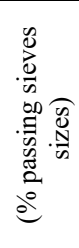 } & $9.5 \mathrm{~mm}$ & & 100 \\
\hline & $4.75 \mathrm{~mm}$ & & 99.6 \\
\hline & $2.36 \mathrm{~mm}$ & & 98.7 \\
\hline & $1.18 \mathrm{~mm}$ & & 97.68 \\
\hline & $0.6 \mathrm{~mm}$ & & 96.7 \\
\hline & $0.425 \mathrm{mn}$ & & 96.2 \\
\hline & $0.3 \mathrm{~mm}$ & & 95.66 \\
\hline & $0.15 \mathrm{~mm}$ & & 94.92 \\
\hline \multicolumn{2}{|c|}{$\%$ Fines } & $0.075 \mathrm{~mm}$ & 94.48 \\
\hline \multicolumn{4}{|c|}{$\%$ Clay particles } \\
\hline \multicolumn{4}{|c|}{ Consistency } \\
\hline \multicolumn{3}{|c|}{ Liquid limit \% } & 50.3 \\
\hline \multicolumn{3}{|c|}{ Plastic limit \% } & 28.5 \\
\hline \multicolumn{3}{|c|}{ Plasticity Index \% } & 21.8 \\
\hline \multicolumn{4}{|c|}{ Other properties } \\
\hline \multicolumn{3}{|c|}{ Specific Gravity $\left(\mathrm{G}_{\mathrm{s}}\right)$} & 2.52 \\
\hline \multicolumn{3}{|c|}{ Optimum Moisture Content (Standard proctor) \% } & 25.5 \\
\hline \multicolumn{3}{|c|}{ Maximum Dry Density (Standard proctor), $\mathrm{Kg} / \mathrm{m}^{3}$} & 1197 \\
\hline \multicolumn{4}{|c|}{ Soil Classification } \\
\hline \multicolumn{3}{|c|}{ USCS } & $\mathrm{CL}$ \\
\hline \multicolumn{3}{|c|}{ Group Index } & 23.2 \\
\hline \multicolumn{3}{|c|}{ AASHTO } & A-7-6 \\
\hline
\end{tabular}

Table 2. Oxide composition of Ikere clay

\begin{tabular}{|c|c|c|c|c|c|c|c|c|c|}
\hline \multicolumn{10}{|c|}{ Ikere clay } \\
\hline $\begin{array}{l}\text { Oxide } \\
\% \text { composition }\end{array}$ & $\begin{array}{l}\mathrm{SiO}_{2} \\
40.58\end{array}$ & $\begin{array}{l}\mathrm{CaO} \\
0\end{array}$ & $\begin{array}{l}\mathrm{Al}_{2} \mathrm{O}_{3} \\
27.03\end{array}$ & $\begin{array}{l}\mathrm{Fe}_{2} \mathrm{O}_{3} \\
17.6\end{array}$ & $\begin{array}{l}\mathrm{K}_{2} \mathrm{O} \\
0.35\end{array}$ & $\begin{array}{l}\mathrm{Na}_{2} \mathrm{O} \\
0.02\end{array}$ & $\begin{array}{l}\mathrm{SO}_{3} \\
0.01\end{array}$ & $\begin{array}{l}\mathrm{MgO} \\
0.49\end{array}$ & $\begin{array}{l}\mathrm{P}_{2} \mathrm{O}_{5} \\
0.15\end{array}$ \\
\hline \multicolumn{10}{|c|}{$\begin{array}{c}\text { Source :( Akinyemi et al., 2014) } \\
\text { Table 3. Oxide composition of the additives }\end{array}$} \\
\hline \multicolumn{10}{|c|}{$\begin{array}{l}\text { Additives } \\
\end{array}$} \\
\hline & $\mathrm{SiO}_{2}$ & $\mathrm{CaO}$ & $\mathrm{Al}_{2} \mathrm{O}_{3}$ & $\mathrm{Fe}_{2} \mathrm{O}_{3}$ & $\mathrm{~K}_{2} \mathrm{O}$ & $\mathrm{Na}_{2} \mathrm{O}$ & $\mathrm{SO}_{3}$ & $\mathrm{MgO}$ & $\mathrm{P}_{2} \mathrm{O}_{5}$ \\
\hline PKSP \% composition & 1.5 & 7.5 & 0.166 & 6.2 & 0.004 & 0.021 & 0.78 & 0.164 & 0.009 \\
\hline SSP $\%$ composition & 2.15 & 25.7 & 0.282 & 1.88 & 0.014 & 0.018 & 0.034 & 0.196 & 0.0029 \\
\hline
\end{tabular}

Effect of PKSP and SSP powders on compaction characteristics of the soil: Compaction characteristics of the stabilized soil is shown in Fig. 1. During compaction, there is a reduction in voids which is as a result of packing of soil particles. Water serves as the lubricant and enable the packing of soil particles. The Maximum Dry Density improves with increase in Snail shell and Palm kernel Shell powder contents except when stabilized with $10 \%$ SSP. A reduction in the MDD at 10\% snail shell powder content indicates that the snail shell content in the soil was in excess of the amount needed to improve the geotechnical characteristics of the soil. The significant improvement may be attributed to the little presence of Cao in the additives. Other factors that could have been responsible for this improvement are cation exchange reactions and consequently formation of new compounds (Onyelowe and Duc 2018). The Optimum Moisture Content (OMC) of the stabilized soil showed a consistent decline except for soil matrix stabilized with $10 \%$ SSP and $10 \%$ PKSP, though the maximum was recorded at $10 \%$ SSP. This behaviour may be due to cation exchange reactions as well as higher water absorption affinity between the soil and the additives at $10 \%$. However, the behaviour of the stabilized soil mixture containing the combination of the additives in ratios of $2 \%: 8 \%, 4 \%: 6 \%, 6 \%: 4 \%$ and $8 \%: 2 \%$ of SSP and PKSP respectively are shown in Fig. 2.Soil mixtures with $2 \%: 8 \%, 4 \%: 6 \%$ and $8 \%: 2 \%$ ratio of SSP and PKSP respectively recorded remarkable improvement in the MDD, although with a non-definite trend in OMC. There was a reduction in OMC of 
soil containing 2\%: $8 \%, 6 \%: 4 \%$ and $8 \%: 2 \%$ ratio of SSP and PKSP respectively.

Table 4. Elemental composition of the additives

\begin{tabular}{|c|c|c|c|c|}
\hline Sample Name & SSP & & PKSP & \\
\hline Test Time(s) & 100 & & 100 & \\
\hline Work Curve & ORE & & ORE & \\
\hline Voltage(KV) & 40 & & 40 & \\
\hline $\operatorname{Current}(\mu \mathrm{A})$ & 350 & & 350 & \\
\hline Element & Intensity & Content & Intensity & Content \\
\hline $\mathrm{Mg}$ & 0.0000 & 0.0000 & 0.0000 & 0.0000 \\
\hline $\mathrm{Al}$ & 0.0012 & 0.3692 & 0.0006 & 0.1595 \\
\hline $\mathrm{Si}$ & 0.0060 & 0.5176 & 0.0080 & 0.7156 \\
\hline $\mathrm{P}$ & 0.0068 & 0.3224 & 0.0037 & 0.1717 \\
\hline $\mathrm{S}$ & 0.0069 & 0.5042 & 0.0077 & 0.5742 \\
\hline $\mathrm{K}$ & 0.0000 & 0.0000 & 0.0084 & 0.6805 \\
\hline $\mathrm{Ca}$ & 0.6652 & 65.2849 & 0.0069 & 0.1145 \\
\hline $\mathrm{Ti}$ & 0.0000 & 0.0000 & 0.0001 & 0.0000 \\
\hline $\mathrm{V}$ & 0.0001 & 0.0045 & 0.0002 & 0.0092 \\
\hline $\mathrm{Cr}$ & 0.0001 & 0.0000 & 0.0001 & 0.0027 \\
\hline $\mathrm{Mn}$ & 0.0003 & 0.0116 & 0.0003 & 0.0153 \\
\hline Co & 0.0001 & 0.0014 & 0.0003 & 0.0051 \\
\hline $\mathrm{Fe}$ & 0.0016 & 0.2355 & 0.0068 & 0.7306 \\
\hline $\mathrm{Ni}$ & 0.0005 & 0.0273 & 0.0016 & 0.0974 \\
\hline $\mathrm{Cu}$ & 0.0010 & 0.0209 & 0.0033 & 0.0560 \\
\hline $\mathrm{Zn}$ & 0.0017 & 0.0551 & 0.0045 & 0.1547 \\
\hline As & 0.0000 & 0.0000 & 0.0001 & 0.0000 \\
\hline $\mathrm{Pb}$ & 0.0001 & 0.0019 & 0.0002 & 0.0021 \\
\hline W & 0.0002 & 0.0334 & 0.0005 & 0.1801 \\
\hline $\mathrm{Au}$ & 0.0000 & 0.0228 & 0.0000 & 0.0000 \\
\hline $\mathrm{Ag}$ & 0.0000 & 0.0007 & 0.0000 & 0.0000 \\
\hline $\mathrm{Rb}$ & 0.0000 & 0.0000 & 0.0001 & 0.0004 \\
\hline $\mathrm{Nb}$ & 0.0000 & 0.0000 & 0.0031 & 0.0329 \\
\hline Mo & 0.0024 & 0.2245 & 0.0033 & 0.1951 \\
\hline $\mathrm{Cd}$ & 0.0000 & 0.0000 & 0.0000 & 0.0000 \\
\hline $\mathrm{Sn}$ & 0.0023 & 0.4185 & 0.0074 & 1.3858 \\
\hline $\mathrm{Sb}$ & 0.0033 & 0.4010 & 0.0093 & 1.1663 \\
\hline
\end{tabular}

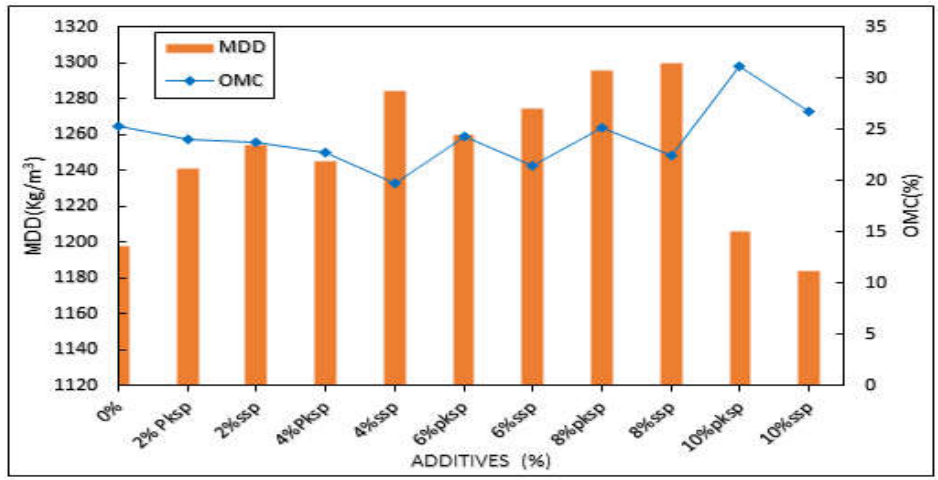

Fig 1. Compaction characteristics of the soil stabilized with varying PKSP and SSP.

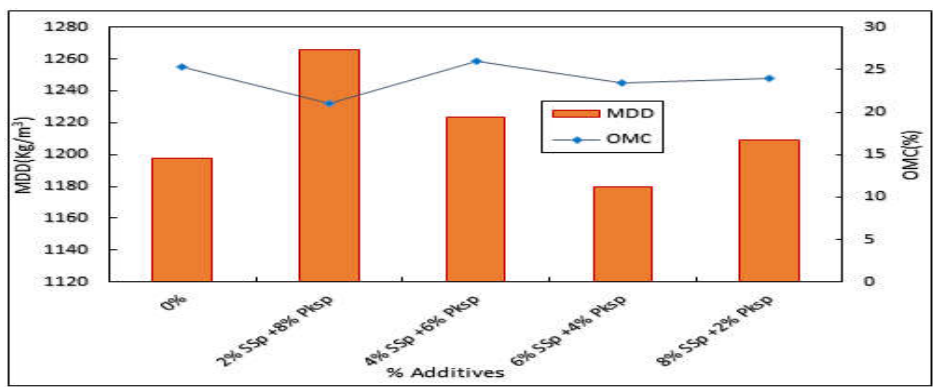

Fig. 2. Compaction characteristics of the soil stabilized with combined PKSP and SSP
Effect of PKSP and SSP powders on consistency of the soil: Consistency limits behaviour of the soil stabilized with SSP and PKSP content (\%) is shown in Fig. 3. Liquid limit reduced at all additive content (\%) except at $4 \%$ PKSP, $6 \%$ SSP and $10 \%$ PKSP while plastic limit also increased when SSP and PKSP was added at 2, 4 and $8 \%$.The stabilized soil matrix also recorded improvement in its plastic limit at $6 \% \mathrm{SSP}, 10 \%$ SSP.It is observed that there was increase in plastic limit of the stabilized matrix when SSP was added. This may be due to high water absorption affinity between SSP and the soil. Consequently, plasticity index of the stabilized soil matrix reduced at addition of $2 \%, 4 \%$, and $8 \%$ of both SSP and PKSP while it also reduced $10 \%$ addition of SSP. The reduction in Plasticity Index (PI) pointed out the improvement in the soil workability (Harichane et al., 2011). However, the consistency behaviour of the stabilized soil mixture containing the combination of the additives in ratios of $2 \%: 8 \%$, $4 \%: 6 \%, 6 \%: 4 \%$ and $8 \%: 2 \%$ of SSP and PKSP respectively are shown in Fig. 4. There was a reduction in the Liquid Limit of the soil containing the combination ratios of SSP and PKSP respectively. Aside 6\%:4\% ratio of SSP and PKSP respectively, all the combination reduced the Plasticity Index (PI) of the soil. There was also decrease in Plastic Limit of the stabilized soil with all the combinations except for $2 \%: 8 \%$ ratio of SSP and PKSP respectively.

Effect of PKSP and SSP powders on $C B R$ of the soil: The measure of the mechanical strength of soil used for highway construction is done using the CBR results. A major assessment for the foundation (Subgrade) of a road is CBR. Fig. 5 showed the mechanical strength of the natural and stabilized soil mixture. Although the highest CBR value obtained either at $2.5 \mathrm{~mm}$ or 
$5 \mathrm{~mm}$ penetration is usually taken as the CBR value.

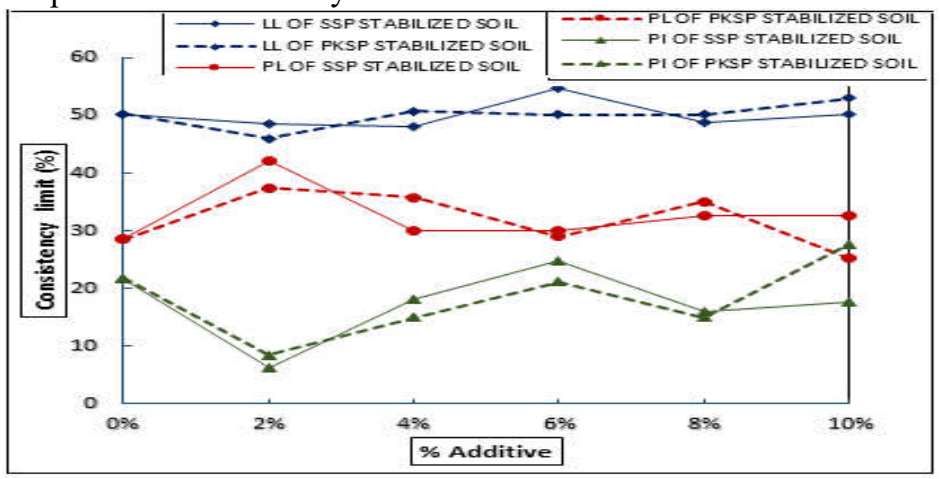

Fig. 3. Consistency behaviour of the soil stabilized with varying PKSP and SSP.

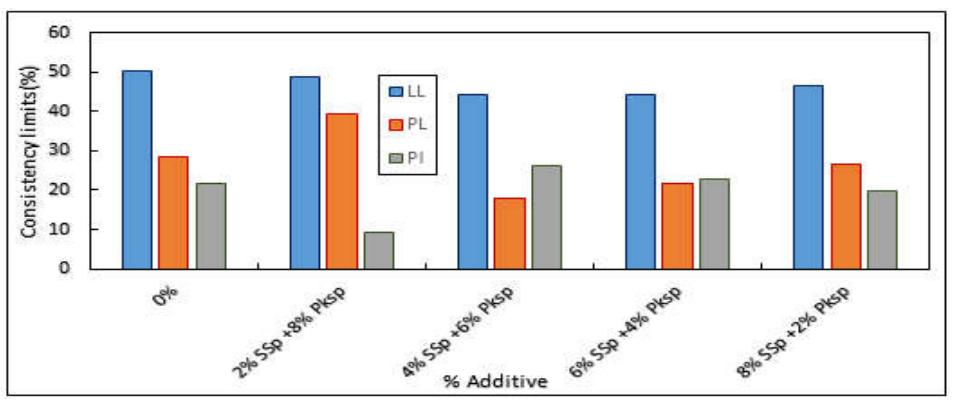

Fig. 4. Consistency behaviour of the soil stabilized with combined PKSP and SSP

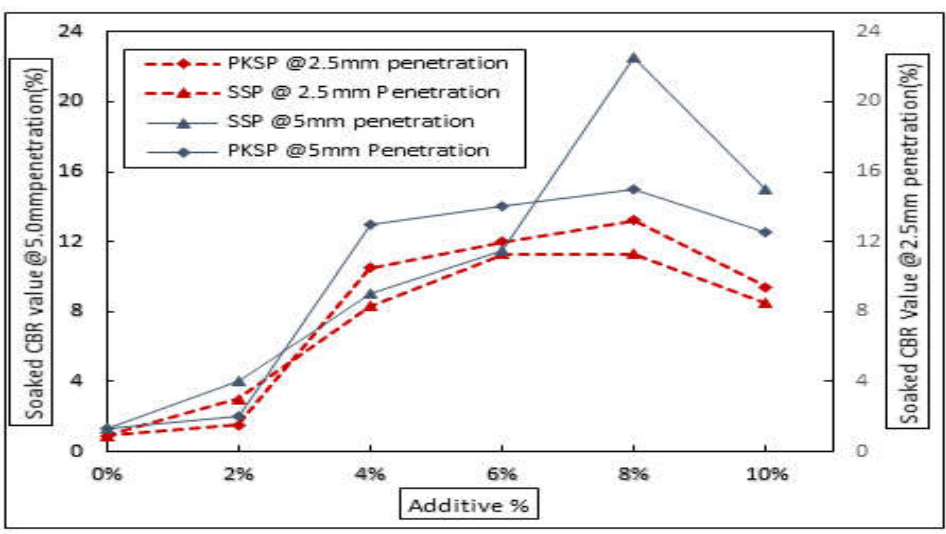

Fig. 5. CBR behaviour of the soil stabilized with varying PKSP and SSP

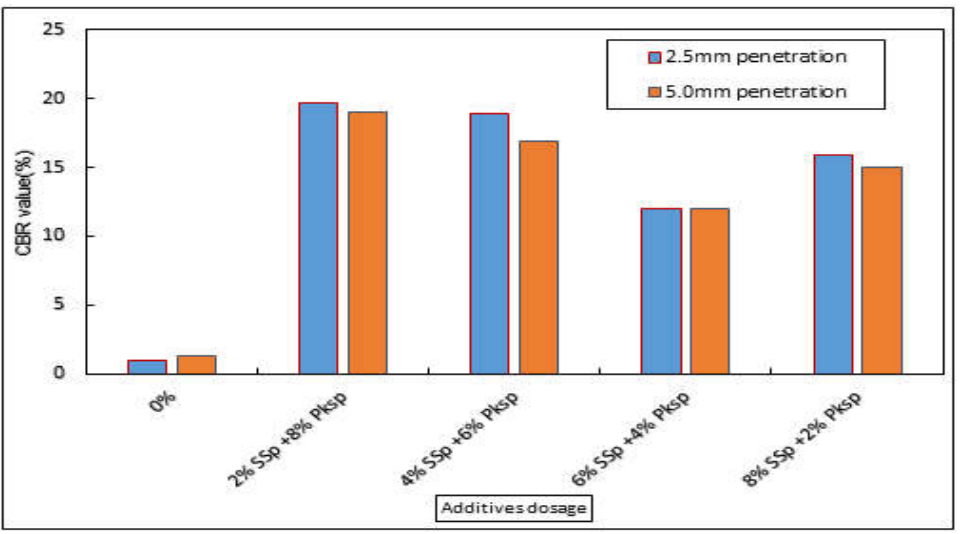

Fig. 6. CBR behaviour of the soil stabilized with combined PKSP and SSP
The behaviour of stabilized soil mixture at different penetration is presented. The natural soil is not fit for highways materials as it value is less than $<3 \%$ and $5 \%$ for fill and subgrade materials respectively (FMW,1997). There is a consistent increase in CBR values when stabilized with the two additives at all the dosages except a consistent decline at $10 \% \mathrm{SSP}$ and $\mathrm{PKSP} \%$. This infers that the load bearing capacity improves tremendously from $1.3 \%$ being the value for the natural soil to $22.5 \%$ (the highest) when stabilized $8 \%$ SSP. At 2\% addition, SSP-stabilized mixture performed better than at $4 \%$ and $6 \%$ addition where PKSP improved the CBR better. The rapid improvement in soaked CBR indicates that the natural soil which was not fit for highways materials ordinarily gained strength after being stabilized with the additives. Summarily, soil mixture stabilized with $8 \%$ SSP and PKSP respectively offered the optimal mixture. However, the CBR behaviour of the stabilized soil mixture containing the combination of the additives in ratios of $2 \%: 8 \%, 4 \%: 6 \%, 6 \%: 4 \%$ and $8 \%: 2 \%$ of SSP and PKSP respectively are shown in Fig. 6. There was remarkable improvement in the CBR values of stabilized soil mixture containing all the combination ratios of SSP and PKSP respectively. Although, the improvement is highest in stabilized soil mixture containing 2\%:8\% ratio of SSP and PKSP respectively and lowest in $6 \%: 4 \%$ ratio of SSP and PKSP respectively. With the improvement in the CBR values, the stabilized soil mixture satisfied the specified requirement for soil suitable for fill.

Conclusion: The assessment of the natural and stabilized soil properties showed that the A-7-6 soil improve remarkably in compaction characteristics as well as plasticity behaviour. 
Also, improved strength (CBR) of the stabilized matrix was observed. These results lend credence to the veracity of the additives as alternative stabilizing materials usable for road construction purposes and also in complementing lime or cement. The use of these additives will stimulate agricultural revolution and reduce highway cost, especially in Nigeria which is not an industrial-based country

\section{REFERENCES}

Abdulkadir, TS; Oyejobi, DO; Lawal, AA (2014). Evaluation of Sugarcane Bagasse Ash as a Replacement for Cement in Concrete Works. Acta Tehnica Corviniensis-Bull. Eng. 71-76.

Adetoro, AE; Faluyi, SO (2015). Potentials of NonCementitious Additives for Stabilization of Oye Local Government Area Soil, Ekiti State Nigeria. Int. J. Sci. Res. Know. 3(11): 288-296,

Akinyemi, SA; Ogunniyi, SO; Ojo, AO; Gitari, WM; Momoh, A; Akinola, OO; Talabi, AO; Afolagboye, LO; Olaolorun, OA; Ayodele, SO (2014). Mineralogy, Physicochemical Characteristics and Industrial Potential of Some Residual Clay Deposits within Ekiti State, Southwestern Nigeria. J. Environ. Earth Sci. 4(17): 70-88.

Alavez-Ramirez, R; Montes-Garcia, P; MartinezReyes, J; Altamirano-Juarez, DC; Gochi-Ponce, Y (2012). The Use of Sugarcane Bagasse Ash and Lime to Improve the Durability and Mechanical Properties of Compacted Soil Blocks. Constr. Build. Mat. 34: 296-305,

Amu, OO; Adetuberu, AA (2010). Characteristics of Bamboo Leaf Ash Stabilization on Lateritic Soil in Highway Construction. Int. J. Eng. Tech. 2(4): 212-219.

Amu, OO; Salami, BA (2010). Effect of Common Salt on Some Engineering Properties of Eggshell Stabilized Lateritic Soil. ARPN J. Eng. App. Sci. 5(9): 64-73.

Ashish Johnson, AT; Krishnankutty, SV (2017). Expansive Soils Stabilization using Coconut Shell Powder and Lime. Int. J. Eng. Res. Tech. 6(3): 541-543.

Ayeni, IS; Ayodele, FO (2015). Compressive Strength Evaluation of Concrete: A Paradigmatic Use of Waste (Sawdust and Cow Dung). Int. J. Eng. Sci. Res. Tech. 4(10): 13-18.
Basha, EA; Hashim, R; Mahmud, HB; Muntohar, AS (2005). Stabilization of Residual Soil with Rice Husk Ash and Cement. Constr. Build. Mat. 19: $448-453$,

Bello, AA; Ige, JA; Ayodele, H (2015). Stabilization of Lateritic Soil with Cassava Peels Ash. Brit. J. App. Sci. Tech. 7(6): $642-650$,

Brahmachary, TK; Rokonuzzaman, R (2018). Investigation of Random Inclusion of Bamboo Fibre on Ordinary Soil and its Effect on CBR Value. Int. J. Geo Eng. 9(10): 2-11,

BS 1377-2. (1990). Methods of Testing Soils for Civil Engineering Purposes. London: British Standard Institute.

Butt, WA; Gupta, K; Jha, JN (2016). Strength Behavior of Clayey Soil Stabilized with Saw Dust Ash. Int. J. Geo-Eng. 7(18): 1-9, https://doi.org 10.1186/s40703-016-0032-9.

Danso, H; Martinson, B; Ali, M; Williams, JB (2015). Effect of Sugarcane Bagasse Fibre on the Strength Properties of Soil Blocks. First International Conference on Bio-Based Building Materials. 17. 2015, Clermont-Ferrand, France.

Duc, BV; Onyelowe, K (2018). Adsorbed Complex and Laboratory Geotechnics of Quarry Dust (QD) Stabilized Lateritic Soils. Environ. Tech. Inn. 10: 355-363, https://doi.org/10.1016/j.eti.2018.04.005.

Edeh, JE; Manasseh, J; Banga, U (2012). Palm Kernel Shell Ash Stabilization of Reclaimed Asphalt Pavements as Highway Pavement Materials. J. Sust. Dev. Environ. Proct. 2(1): 98-110.

Edewor, JO; Jemni, RO (1990). Cellulosic Waste as Sources of Organic Chemicals: Some Fundamental Considerations. J. Nig. Soc. Chem. Eng. 1(1): 153-158.

Federal Ministry of Works, Nigeria. (1997). Specification Limits For Materials and Workmanship. General specification for roads and Bridges.

Gardner, KH (2011). Life Cycle Perspectives of Recycled Materials Use in Civil Engineering. Program and Abstracts of ASTM International Symposium on Testing and Specification of Recycled Materials for Sustainable Geotechnical Construction, 53. 
Gomes, CA; Reis, FS; Fortunato, E (2011). Case Study to Promote the Use of Byproducts: the Relevance of Performance Tests. Program and Abstracts of ASTM International Symposium on Testing and specification of Recycled Materials for Sustainable Geotechnical Construction, 25.

Harichane, K; Ghrici, M; Kenai, S; Grine, K (2011). Use of Natural Pozzolana and Lime for Stabilization of Cohesive Soils. Geotech. Geolo. Eng. 29(5): 757-769,

Hossain, KMA; Lachemi, M; Easa, S (2007). Stabilized Soils for Construction Applications Incorporating Natural Resources of Papua New Guinea." Res. Conserv. Recyc. 51(4): 711-731,

Hossain, Z; Solanki, P; Zaman, M; Lewis, AS; Hobson, K (2011). Influence of Recovery Processes on Properties of Binders and Aggregates Recovered from Recycled Asphalt Pavement. Program and Abstracts of ASTM International Symposium on Testing and specification of Recycled Materials for Sustainable Geotechnical Construction, 13.

Igwe, O; Adepehin, EJ (2017). Alternative Approach to Clay Stabilization Using Granite and Dolerite Dusts. Geotech. Geolo. Eng. 35(4): 1657-1664, https:// doi.org/10.1007/s10706-017-0200-5.

Jiksymol, KJ; Anu, P; Anumol, VS; Fathima, M; Alka, A (2014). Studies on Improvement of Clayey Soil using Egg Shell Powder and Quarry Dust. Int. J. Eng. Res. App. 4(4): 55-63.

Johns, D; Joseph, N; Prasath, SN (2017). Improvement of Subgrade Clayey Soil using Eggshell. Int. J. Res. App. Sci. Eng. Tech. 5(3): 983-989.

Karthika, P.N., M. Noy, P.J. Prabhu, and L.J. Tess. 2016. "Effect of Curing on Soil Stabilized with Egg Shell.” Int. J. Sci. Tech. Eng. 2(12): 258-264.

Kavyashree, MP; Renukaprasad, MS; Maruti, RN (2016). Black Cotton Soil Stabilization Using Eggshell Powder and Lime. Int. J. Sci. Res. Dev. 2(10): 1-8.

Mounika, K; Narayana, BS; Manohar, D; Vardhan, KS (2014). Influence of Sea Shells Powder on Black Cotton Soil during Stabilization. Int. J. Adv. Eng. Tech. 7(5): 1476-1482.

Nnochiri, ES; Ogundipe, OM; Oluwatuyi, OE (2017). Effects of Palm Kernel Shell Ash on LimeStabilized Lateritic Soil. Slov. J. Civ. Eng.
25(3):1-7, http://dx.doi.org/10.1515/sjce-20170012 .

Nnochiri, ES; Ogundipe, OM (2016). Geotechnical Properties of Lateritic Soils Stabilized with Groundnut Husk Ash. Civ. Eng. Jour. 2(11): 568575.

Olutaiwo, AO; Adanikin, A (2016). Evaluation of the Structural Performance of Lateritic Soil Stabilized with Cassava Peel Ash (CPA) and Cement. Int. J. Constr. Res. Civ. Eng. 2(2): 18-26.

Ogunribido, THT (2012). Geotechnical Properties of Sawdust Ash Stabilized Southwestern Nigeria Lateritic Soils. Environ. Res. Eng. Manage. 2(60): 29-33,

Obi, FO; Ugwuishiwu, BO; Nwakaire, JN (2016). Agricultural Waste Concept, Generation, Utilization and Management. Nig. J. Tech. 35(4): 957-964.

Ogundipe, OM (2013). An Investigation into the Use of Lime-Stabilized Clay as Subgrade Material. Int. J. Sci. Tech. Res. 2(10): 82 -86.

Okonkwo, UN; Odiong, IC; Akpabio, EE (2012). The Effects of Eggshell Ash on Strength Properties of Cement Stabilized Lateritic. Int. J. Sust. Constr. Eng. Tech. 3(1): 18-25.

Okunade, EA (2010). Geotechnical Properties of Some Coal Fly Ash Stabilized Southwestern Nigeria Lateritic Soils. Mod. App. Sci. 4(12): 6673.

Olanipekun, EA; Olusola, KO; Ata, O (2006). A comparative Study of Concrete Properties using Coconut Shell and Palm Kernel Shell as Coarse Aggregates. Build. Environ. 41: 297 - 301,

Olofintuyi, IO; Oluborode, KD; Adegbite, I (2015). Structural Value of Bamboo Leaf Ash as a Pozzolanic Material in a Blended Portland Cement. Int. J. Eng. Sci. Res. Tech. 4(9): 171-177.

Oluwatuyi, EO; Ojuri, OO (2017). Environmental Performance of Lime - Rice Husk Ash Stabilized Lateritic Soil Contaminated with Lead or Naphthalene. Geotech. Geolo. Eng. 35(6): 29472964 ,

Onyelowe, KC; Duc, BV (2018). Durability of Nanostructured Biomasses Ash (NBA) Stabilized Expansive Soils for Pavement Foundation. Int. J. of Geotech. Eng. 1-10, 
Osinubi, KJ; Edeh, JE (2011). Reconstituted coal ash stabilization of reclaimed asphalt pavement. GeoFrontiers Congress Advances in Geotechnical Engineering. 1172-1181. 2011, Dallas, Texas, USA.

Oyedepo, OJ; Olanitori, LM; Akande, SP (2015). Performance of Coconut Shell Ash and Palm Kernel Shell Ash as Partial Replacement for Cement in Concrete. J. Build. Mat. Struct. 2(1): 18-24.

Phanikumar, BR; Sharma, R (2007). Volume Change Behavior of Fly Ash-Stabilized Clays. J. Mat. Civ. Eng. 19(1): 67-74,

Phanikumar.BR; Nagaraju, TV (2018). Effect of Fly Ash and Rice Husk Ash on Index and Engineering Properties of Expansive Clays. Geotech. Geolo. Eng. 35(6): 1-12,

Salau, MA; Ikponmwosa, EE; Olonade, KA. (2012). Structural Strength Characteristics of CementCassava Peel Ash Blended Concrete. Civ. Environ. Res. 2(10): 68-77.

Salim, RW; Ndambuki, JM; Adedokun, DA (2014). Improving the Bearing Strength of Sandy Loam Soil Compressed Earth Block Bricks using Sugarcane Bagasse Ash. Sust. 6: 3686-3696,
Sanjay, S; Rajeev, C (2015). Effect of Coconut Fibre Ash on Strength Properties of Concrete. Int. J. Eng. Res. App. 5(4): 33-35.

Sujatha, ER; Dharini, K; Bharathi, V (2016). Influence of Groundnut Shell Ash on Strength and Durability Properties of Clay. Geomech. Geoeng. 11(1): 20-27,

Sunil, H; Adnan, M; Krithesh, Preston, L (2016). Improvement of Lateritic Soil using Eggshell Powder and Marble Dust and its Comparison with Lime Stabilized Clay. Int. J. Adv. Mech. Civ. Eng. 28-30.

Vilane, BRT (2010). Assessment of Stabilization of Adobes by Confined Compression Tests. Biosys. Eng. 106 (4): 551-558,

Wen, H; Wu, M (2011). Evaluate High Percentage Rap as Base Course Material. Program and Abstracts of ASTM International Symposium on Testing and specification of Recycled Materials for Sustainable Geotechnical Construction, 2-4. 2011, Baltimore, U.S.A.

Worrell, E; Price, L; Martin, N; Hendriks, C; Meida, LO (2001). Carbon Dioxide Emissions from the Global Cement Industry. Ann. Rev. of Ener. Environ. 26: 303-329 